Wojciech Rzechorzek', Michalina Szańkowska', Benedykt Szczepankiewicz' ${ }^{2}$ Agata Cyran-Chlebicka², Aleksandra Safianowska ${ }^{3}$

'Student Interest Group "Alveolus", Department of Internal Diseases, Pulmonology, and Allergology, Medical University of Warsaw,

Poland

Tutor: Prof. J. Domagała-Kulawik, MD, PhD

${ }^{2}$ Chair and Department of Pathomorphology, Medical University of Warsaw, Poland

Head: Prof. B. Górnicka, MD, PhD

${ }^{3}$ Department of Internal Diseases, Pulmonology, and Allergology, Medical University of Warsaw, Poland

Head: Prof. R. Chazan, MD, PhD

\title{
Detecting Mycobacterium tuberculosis complex DNA, based on post-mortem examination of hilar lymph nodes with real-time PCR: initial study
}

\author{
Wykrywanie DNA Mycobacterium tuberculosis complex, na podstawie badania \\ post mortem węztów chłonnych wnękowych, metodą real-time PCR — doniesienie \\ wstępne
}

Study supported by Medical University of Warsaw, Poland, Grant № 1wu/nm1/11

\begin{abstract}
Introduction: According to the WHO, almost a third of the world population are thought to be infected with Mycobacterium tuberculosis. Some studies of the prevalence of latent tuberculosis infection (LTBI) have already been performed in Poland, showing that almost a quarter of the Mazovia population could be infected. It also indicated a higher prevalence of LTBI among seniors. Those studies were based on indirect diagnostic methods.

Material and methods: We randomly collected hilar lymph nodes from decedents aged 40 years and older during post-mortem examination. We excluded patients with previous confirmed tuberculosis. In addition, an autopsy was performed in all patients. Finally, we used real-time PCR Xpert MTB/RIF (Cepheid, USA) for the specific capture of mycobacterial DNA.

Results: Twenty-two of 23 patients had a negative result of the real-time PCR examination and no signs of caseous necrosis in hilar lymph nodes. We found the only positive sample in a patient with histopathological signs of tuberculosis (the presence of caseous necrosis in the specimens obtained from lymph nodes and lung). Due to the change of cartridges from version $\mathrm{G} 3$ to $\mathrm{G} 4$, further reactions were inhibited and no more post-mortem samples were tested.

Conclusions: Real-time PCR Xpert MTB/RIF was capable of detecting M. tuberculosis complex DNA in a patient with tuberculosis recognised on autopsy. In the remaining patients, no $M$. tuberculosis complex DNA was found, in accordance with negative results of histological examination. Since the technology of cartridges has changed, it is no longer possible to use real-time PCR Xpert MTB/RIF (Cepheid USA) on post-mortem material.
\end{abstract}

Key words: M. tuberculosis complex DNA, latent tuberculosis infection, real-time PCR, Xpert MTB/RIF

Pneumonol. Alergol. Pol. 2014; 82: 430-435

Address for correapondence: W. Rzechorzek, Student Interest Group "Alveolus", Department of Internal Diseases, Pulmonology, and Allergology, ul. Banacha 1a 02-097 Warsaw, Poland, Tel.: +48 605160 106, e-mail: wrzechorzek@gmail.com

DOI: 10.5603/PiAP.2014.0056

Praca wpłynęła do Redakcji: 22.07.2013 r.

Copyright (C) 2014 PTChP

ISSN 0867-7077 


\section{Streszczenie:}

Wstęp: Zgodnie z danymi Światowej Organizacji Zdrowia, uważa się, że prawie 1/3 światowej populacji jest zakażona prątkiem gruźlicy. Wyniki badań prowadzonych przy użyciu pośrednich metod diagnostycznych nad rozpowszechnieniem utajonego zakażenia prątkiem gruźlicy w Polsce wykazały, że nawet 1/4 populacji Mazowsza może być zakażona, z przewagą u osób starszych. Materiał i metody: Podczas badania post-mortem pobierano w sposób losowy węzły chłonne wnękowe od zmarłych w wieku 40 lat i powyżej. Na podstawie danych z historii chorób wykluczono pacjentów leczonych z powodu gruźlicy w przeszłości. U wszystkich chorych przeprowadzono badanie sekcyjne. Następnie wykonywano badanie real-time PCR, Xpert MTB/RIF, Cepheid, USA w celu wykrycia DNA Mycobacterium tuberculosis complex.

Wyniki: U 22 z 23 pacjentów wynik reakcji real-time PCR był negatywny, a w preparatach węzłów chłonnych nie stwierdzono ziarniny serowaciejącej. W jednym przypadku badanie real-time PCR było dodatnie. Dotyczyło to chorego, u którego stwierdzono obecność ziarniny serowaciejącej zarówno w preparatach z węztów chłonnych, jak i pobranych z nacieku płucnego. Po zmianie kartridży z wersji G3 na G4 w real-time PCR, Xpert MTB/RIF kolejne reakcje były zahamowane i nie testowano większej liczby próbek.

Wnioski: Badanie metodą real-time PCR, Xpert MTB/RIF wykazało obecność M. tuberculosis complex DNA u chorego z pośmiertnie stwierdzoną gruźlicą płuc i ww. chłonnych. U pozostałych chorych nie wykryto obecności DNA $M$. tuberculosis complex w tkankach, co pozostawało w zgodzie z negatywnym wynikiem badania histologicznego. Po zmianie technologii badania real-time PCR, Xpert MTB/RIF zawodzi przy badaniu próbek z materiału uzyskanego pośmiertnie.

Słowa kluczowe: gruźlica utajona, real-time PCR, Xpert MTB/RIF

Pneumonol. Alergol. Pol. 2014; 82: 430-435

\section{Introduction}

According to the WHO, almost a third of the world population could be infected with M. tuberculosis [1]. In countries endemic for TB, the greatest number of new cases of tuberculosis is the result of recent contact with an infectious case of tuberculosis, whereas in developed countries with low prevalence of pulmonary TB, new cases of TB appear to be due to the reactivation of LTBI [2].

Latent tuberculosis infection (LTBI) is a condition in which M. tuberculosis is suppressed by the immune response of the host. Although tubercle bacillus does not replicate, it remains in old lesions. There are two models describing the possible location of the bacilli during the latency. In the "focal" model, M. tuberculosis remains in old granulomatous lesions and draining regional lymph nodes, which correspond to the Gohn complex. According to the "diffuse" model, bacilli are distributed all over the lungs and other tissues [3]. A patient with LTBI does not transmit the disease, in contrast to the active form of tuberculosis (TB), in which the host infects up to 10-30 people per year [4].

The incidence of tuberculosis per 100,000 population in Europe is 50 in Lithuania and Estonia and 10-20 in the United Kingdom, France, and Germany. In Poland after World War II the incidence of tuberculosis was very high, reaching over 300 per 100,000 population, and remained high until the 1960s, when it started to decrease gradually partly as a result of previous introduction of successful anti-tuberculous treatment [4]. Afterwards, the permanently declining incidence rate of tuberculosis led to similar levels to those seen in developed countries, i.e. 19.6 per 100,000 population in 2012 [5].

The incidence notification rates of TB differ depending on the age group. Among seniors aged 45-64 and 65+ the incidence is much higher than in other age groups, reaching 32.1 and 34.8 per 100,000 population, respectively [5].

Likewise, the prevalence of LTBI according to the results of Kuś et al., based on interferon gamma release assay (IGRA), was higher among older people [6]. In this study it was shown that almost a quarter of the Mazovian population could be infected [6].

Taking into consideration the high prevalence of tuberculosis in Poland in the past and the positive correlation between IGRA results and age, it can be presumed that the incidence of tuberculosis among seniors nowadays could be the result of reactivation of latent infection.

Factors connected with the immunological status of the patient can facilitate the change from dormant bacilli state to clinical manifestation of tuberculosis. These include, among others, immunodeficiency due to immunosuppressive drugs, including anti-TNF therapy, or diseases such as diabetes, cancer, or HIV infection $[7,8]$.

People with latent infection have neither symptoms nor radiographic evidence of active TB. In the absence of bacilli in sputum or any clinical 
probe, LTBI cannot be detected with classical microbiological methods, neither bacterioscopy nor culture. Consequently, there is no gold-standard test to determine LTBI. Current tools to diagnose LTBI include physical examination and history of TB contact. Tuberculin skin test (TST) and IGRA are indirect methods to investigate LTBI, based on the fact that after contact with bacilli, the lymphocytes of the human host are sensitised to M. tuberculosis antigens, and the immunological memory persists. According to the indirect character of the tests, many false positive and false negative results can occur [9]. However, these tests cannot inform us with certainty about the current presence of tubercle bacilli and do not distinguish the past from present infection, regardless of whether or not it is active. Consequently, the exact prevalence of LTBI is not known [10, 11].

Taking into consideration all of the epidemiological and pathophysiological data, we decided to establish whether it is possible to detect M. tuberculosis complex DNA by direct method, real-time PCR, in decedents aged 40 years and older, who were free from clinically recognisable tuberculosis in the past.

\section{Material and methods}

In the first step of our study we randomly collected hilar lymph nodes from decedents aged 40 years and older during post-mortem examinations (Fig. 1). Autopsies were performed on patients from the Central Clinical Hospital in Warsaw. The material was collected by anatomopathologists, placed into a physiological salt solution, and frozen at $-20^{\circ} \mathrm{C}$.

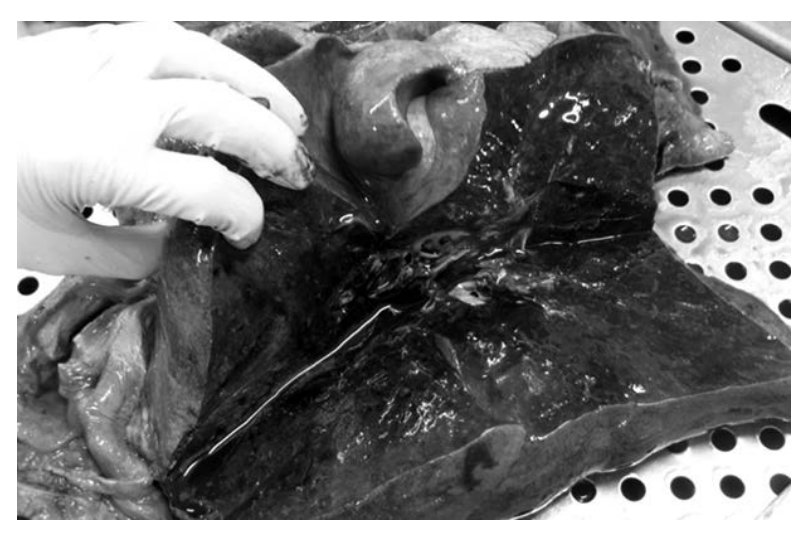

Figure 1. Hilar lymph nodes

Author: Benedykt Szczepankiewicz, MD, PhD Chair and Department of Pathomorphology (7 Pawińskiego str., 02-106 Warsaw, Poland)
In the second step, we analysed medical case histories, chest X-ray examinations, and/or computer tomography (CT) scans of decedents whose lymph nodes were collected. We excluded the material from patients with proven TB in the past. We also excluded the material from decedents with signs of cavitation suggesting active TB. Autopsy was performed in all of the patients.

Finally, to permit the specific capture of mycobacterial DNA, we used real-time PCR, Xpert MTB/RIF, version G3 (Cepheid, USA) [12]. We performed tests as an off label use on tissue specimens, previously validated by our laboratory. We did not use any methods to purify the material from tissue inhibitors. We used the same procedure as in sputum examination, as described in the manufacturer's guidelines [13].

\section{Results}

We examined 23 patients within the age range of 40-97 years (average 70), 8 (35\%) of whom were men. In all of the medical data, we found no signs of active TB. Eight of 23 patients had CT scans of the chest. Focal consolidations either in upper lobes or in superior parts of lower lobes and lymphadenopathy were present in four patients, and isolated lymphadenopathy in one case. No signs of cavitation were present in CT scans. Other results of CT scans are presented in Table 1.

In the examined group, 22 out of 23 patients had a negative result of the real-time PCR and histopathological signs of tuberculosis were not found. The histological results and clinical diagnosis of patients are summarised in Table 1.

The only positive sample was found in a 64-year-old patient with signs of tuberculosis. The autopsy revealed a $4 \times 4 \times 3 \mathrm{~cm}$ white/yellow amorphous lesion consistent with the foci of caseous necrosis, localised in the upper lobe of the right lung. Hilar lymph nodes were enlarged ( $2 \mathrm{~cm}$ in diameter). Microscopic necrosis and granulomatous reaction with multinucleate giant cells were present. The patient was referred to the neurosurgical department because of coma and severe subarachnoid haemorrhage. In addition, he suffered from diabetes and HCV infection. Blood tests, taken before death, revealed CRP - less than $5 \mathrm{mg} / \mathrm{L}[<10 \mathrm{mg} / \mathrm{L}]$ and $\mathrm{WBC}$ of $24.15 \times$ $1000 / \mathrm{mm}^{3}\left[4-10 \times 1000 / \mathrm{mm}^{3}\right]$. After four days of hospitalisation, the patient underwent brain-stem death. There was not enough data in case history or in X-ray examination to establish if the patient was symptomatic. 


\section{Table 1. Individual patients' results}

\begin{tabular}{|c|c|c|c|c|c|}
\hline Gender & Age & $\begin{array}{l}\text { real-time PCR } \\
\text { result } \\
\text { P-positive } \\
\text { N-negative }\end{array}$ & $\begin{array}{l}\text { Clinical } \\
\text { diagnosis of } \\
\text { tuberculosis } \\
\text { A-absent } \\
\text { P-present }\end{array}$ & Thorax CT scan pathologies & Autopsy findings \\
\hline Male & 85 & $\mathrm{~N}$ & $A$ & $\begin{array}{l}\text { Bilateral massive consolidations; Enlarged } \\
\text { para-aortic lymph nodes (I.n.) }\end{array}$ & Oedema/lung congestion \\
\hline Male & 62 & $\mathrm{~N}$ & $A$ & $\begin{array}{l}\text { Bilateral interstitial changes, glass-like infil- } \\
\text { trates; Enlarged right hilar and mediastinal } \\
\text { I.n.; Bilateral pleural effusions }\end{array}$ & Oedema/lung congestion \\
\hline Male & 85 & N & $A$ & $\begin{array}{l}\text { Perihilar inflammatory consolidation, left } \\
\text { lung; Enlarged left, inferior, paratracheal } \\
\text { I.n.; Nodules, left lung, interlobar fissure } \\
(<8 \mathrm{~mm}) \text {; Bilateral pleural effusions }\end{array}$ & Oedema/lung congestion \\
\hline Male & 60 & N & $A$ & $\begin{array}{c}\text { Bilateral enlarged axillary, mediastinal and } \\
\text { cavital I. n.; Nodules, right lung, upper lobe } \\
(4 \mathrm{~mm}) \text {, medial lobe ( } 3 \mathrm{~mm}) \text { and lower lobe } \\
(6 \mathrm{~mm}) \text {; Focal fibrosis- left lung; Pleural } \\
\text { effusions, left lung }\end{array}$ & Enlarged mediastinal lymph nodes \\
\hline Female & 63 & N & $A$ & $\begin{array}{l}\text { Enlarged bilateral axillary, mediastinal and } \\
\text { right cavital I.n.; Bronchial consolidations, } \\
\text { right lung, upper and lower lobes; Consolida- } \\
\text { tions, left lung medial and lower lobes }\end{array}$ & Inflammatory changes in both lungs \\
\hline Male & 75 & N & $A$ & & Congestion/atelectasis \\
\hline Male & 64 & $P$ & $P$ & & $\begin{array}{l}4 \times 4 \times 3 \text {-cm white/yellow amorpho- } \\
\text { us lesion consistent with the foci of ca- } \\
\text { seous necrosis localized in upper lobe } \\
\text { of the right lung, enlarged hilar lymph } \\
\text { nodes ( } 2 \mathrm{~cm} \text { in diameter). Microscopi- } \\
\text { cally necrosis and granulomatous reac- } \\
\text { tion with multinucleate giant cells }\end{array}$ \\
\hline Male & 83 & $\mathrm{~N}$ & A & & Oedema/lung congestion \\
\hline Female & 58 & $\mathrm{~N}$ & A & & Oedema/lung congestion \\
\hline Female & 97 & $\mathrm{~N}$ & $A$ & Nodules, bilateral, partially calcified (small) & Massive bilateral pleural effusion \\
\hline Female & 80 & N & $A$ & & Oedema/lung congestion \\
\hline Female & 70 & N & $A$ & $\begin{array}{l}\text { Nodules left lung } 9 \text { seg. (4 and } 5 \mathrm{~mm} \text { ) Bilateral } \\
\text { basal atelectasis; Bilateral pleural effusions }\end{array}$ & Inflammatory changes in both lungs \\
\hline Female & 61 & N & $A$ & & No changes \\
\hline Male & 63 & $\mathrm{~N}$ & $A$ & & $\begin{array}{c}\text { Purulent bronchitis, emphysema, } \\
\text { focal siderophages, congestion, focal } \\
\text { oedema, }\end{array}$ \\
\hline Male & 64 & N & $A$ & & Oedema/lung congestion \\
\hline Male & 54 & N & $A$ & & $\begin{array}{l}\text { Oedema/congestion, small focal } \\
\text { fibrosis in right lung }\end{array}$ \\
\hline Male & 76 & N & A & & Congestion/atelectasis \\
\hline Male & 40 & N & A & & $\begin{array}{l}\text { Oedema/congestion, purulent } \\
\text { bronchitis }\end{array}$ \\
\hline Female & 58 & N & $A$ & & Lung congestion \\
\hline Female & 89 & N & $A$ & $\begin{array}{l}\text { Enlarged mediastinal I.n.; Focal change, } \\
\text { right lung, } 10^{\text {th }} \text { segment }\left(15^{*} 20 \mathrm{~mm}\right)\end{array}$ & Bronchopneumonia \\
\hline Female & 79 & $\mathrm{~N}$ & A & & $\begin{array}{l}\text { Lung tumour enlarged right hilar lymph } \\
\text { nodes }\end{array}$ \\
\hline Male & 77 & $\mathrm{~N}$ & A & & Atelectasis \\
\hline Male & 57 & N & $A$ & $\begin{array}{l}\text { Enlarged axillar, mediastinal and cavital I.n.; } \\
\text { Bilateral glass-like infiltrates (possible CMV } \\
\text { aetiology); Bilateral basal subpleural nodules }\end{array}$ & $\begin{array}{l}\text { Small nodule in the lower lobe of the } \\
\text { right lung, oedema/congestion, enlar- } \\
\text { ged hilar lymph nodes }\end{array}$ \\
\hline
\end{tabular}




\section{Discussion}

In spite of the vast knowledge of M. tuberculosis and numerous new methods to detect bacilli, there are still unanswered questions in the field of examinations. It is impossible to do the following: estimate the number of people that are infected in a latent manner; fully eliminate bacteria after the primary infection; or predict the risk of progression to the disease in patients with persistent anti-mycobacterial immune responses [10].

The percentage of people exposed to tuberculosis, who develop infection varies from 30 to $95 \%$, according to different specialists $[1,14]$. The majority (90\%) of people exposed to tuberculosis develop localized infection, which in up to $90 \%$ of cases leads to LTBI [15]. Reactivation of the infection is possible in 5-10\% of those cases, even many years after the primary infection [16, 17].

In post-primary $M$. tuberculosis infection, radiological changes include focal consolidations in upper lobes and superior parts of lower lobes, rarely accompanied by lymphadenopathy. Cavitation is a sign of active disease, with high infectivity and higher risk of complications [18].

In the present study, thorax CT scans were obtained in eight patients. Although lung pathology was present in all of them, taking into consideration the negative histopathological examination and the lack of previous diagnosis of tuberculosis, none of them had signs consistent with active TB.

Most LTBI studies are based on indirect methods of investigation, including TST and IGRA $[3,19]$. The aim of our study was to detect $M$. tuberculosis complex DNA using real-time PCR, Xpert MTB/ /RIF (Cepheid, USA) in material from patients with low probability of active tuberculosis. Although the method is designed to detect $M$. tuberculosis complex in sputum and BAL, it is also used with success to test the material from solid tissues, including extra-pulmonary locations $[12,20]$. In a systematic review and meta-analysis, Denkinger et al. noted Xpert MTB/RIF pooled sensitivity of $83.1 \%$ (95\% CI 71.4-90.7\%) and pooled specificity of $93.6 \%$ (95\% CI $87.9-96.8 \%$ ) against culture in material from lymph node tissues or aspirates [21]. This study included results from our laboratory.

In four samples from mediastinal lymph nodes examined with real-time PCR during routine diagnostic procedure, two were positive and none of the reactions were inhibited [13]. The same procedure was performed by our group in 14 different samples, with two positive results [unpublished data]. Tortoli et al. reported that in reference to the culture and clinical diagnosis of TB, sensitivity and specificity of Xpert MTB/ RIF reaches $81.3 \%$ and $99.8 \%$, respectively [22]. According to some authors, there have been successful attempts to detect DNA of M. tuberculosis complex in paraffin-embedded blocks already performed using PCR amplification methods [23, 24].

We used Xpert MTB/RIF, which is based on the Automated Nucleic Acid Amplification Test and is capable of detecting even small amounts of DNA of $M$. tuberculosis complex. Furthermore, $r p o B$ detected with real-time PCR is a very conservative gene present among $M$. tuberculosis complex. Markers used in real-time PCR detect mutations in this gene specific for $M$. tuberculosis complex, including ones responsible for resistance to rifampicin. Research on tuberculosis shows superiority (greater specificity and sensitivity) of real-time PCR over other methods, such as acid-fast bacilli culture or nested PCR [11]. The advantage of the test is the integrated internal control to monitor the validity of the assay, to exclude negative result due to potential polymerase inhibitors present in tissues [25]. In the presented study, all reactions were valid according to performed internal controls.

A drawback of the study with post-mortem material is that IGRA or TST are impossible. Therefore, we had only incomplete medical documentation, CT scans, and histopathological examination to evaluate clinical data and determine potential infections in patients.

Taking into consideration the high sensitivity and specificity of real-time PCR, the epidemiology of TB and LTBI, along with the age of the patients in our group, the chance of obtaining positive results seemed high. In our study we collected hilar lymph nodes, relying on the "focal" model of tuberculosis. However, the "diffuse" model of tuberculosis is a valid alternative, so, to some extent, the distribution of $M$. tuberculosis bacilli could be the cause of negative results. Because of financial limitations, it was not possible to examine whole lungs and all of the mediastinal lymph nodes, possible locations of M. tuberculosis according to the diffuse model.

In the only positive Xpert MTB/RIF case, histopathological examination confirmed the presence of caseous necrosis in lungs and regional lymph nodes, which, combined with a positive result of Xpert MTB/RIF, allowed us to recognise active tuberculosis according to the guidelines of the Polish Society of Lung Diseases [26].

Although initially we wanted to perform 40 reactions, the technology of cartridges in real-time 
PCR Xpert MTB/RIF (Cepheid, USA) has changed. The version (G3) that we were using was replaced by a new version (G4). The technological details of the change between versions of the cartridges were reserved by the manufacturer. We performed three reactions, which were inhibited, so we decided to interrupt our study. Therefore, no more samples were tested.

\section{Conclusions}

Real-time PCR, Xpert MTB/RIF was capable of detecting $M$. tuberculosis DNA in a patient with tuberculosis recognised on autopsy.

In the remaining patients, no $M$. tuberculosis complex DNA was found, which was consistent with the negative results of histological examination.

Since the technology of cartridges has changed, it is no longer possible to use Xpert MTB/RIF on post-mortem material.

\section{Conflict of interest}

The authors declare no conflict of interest.

\section{References:}

1. World Health Organisation. Tuberculosis: fact sheets. http:// www.who.int/mediacentre/factsheets/fs 104/en/index. html;02.07.2014.

2. Amanatidou V., Syridou G., Mavrikou M., Tsolia M.N. Latent tuberculosis infection in children: diagnostic approaches. Eur. J. Clin. Microbiol. Infect. Dis. 2012; 31: 1285-1294.

3. Parrish N.M., Dick D.J., Bishai W.R. Mechanisms of latency in Mycobacterium tuberculosis. Trends Microbiol. 1998; 6: 107-112.

4. Kwiatkowska S. Gruźlica w Polsce i na świecie. Alergia 2008; 2: 41-44.

5. Korzeniewska-Koseła M. ed. Tuberculosis and lung diseases in Poland in 2012. Instytut Gruźlicy i Chorób Płuc, Warszawa 2013; 29.

6. Kus, J., Demkow U., Lewandowska K. et al. Prevalence of latent infection with Mycobacterium tuberculosis in Mazovia Region using interferon gamma release assay after stimulation with specific antigens ESAT-6 and CFP-10. Pneumonol. Alergol. Pol. 2011; 79: 407-418.

7. Mack U., Migliori G.B., Sester M. et al. LTBI: latent tuberculosis infection or lasting immune responses to M. tuberculosis? A TBNET consensus statement. Eur. Respir. J. 2009; 33: 956-973.

8. Kapoor N., Pawar S., Sirakova T.D. et al. Human granuloma in vitro model, for TB dormancy and resuscitation. PLoS One 2013; 8: e53657.
9. Abdalhamid B., Hinrichs S.H., Garrett J.L. et al. Utilization of the QuantiFERON-TB Gold Test in a two - step process with the Tuberculin Skin Test to evaluate health care workers for latent tuberculosis. J. Clin. Microbiol. 2010; 48: 2955-2956.

10. Lee H. S., Park K.U., Park J.O. et al. Rapid, sensitive, and specific detection of Mycobacterium tuberculosis complex by real-time PCR on paraffin-embedded human tissues. J. Mol. Diagn. 2011; 13: 390-394.

11. Norbis L., Miotto P., Alagna R. Cirillo D.M. Tuberculosis: lights and shadows in the current diagnostic landscape. New Microbiol. 2013; 36: 111-120.

12. Helb D., Jones M., Story E. et al. Rapid detection of Mycobacterium tuberculosis and rifampin resistance by use of on-demand, near-patient technology. J. Clin. Microbiol. 2010; 48: 229-237.

13. Safianowska A., Walkiewicz R., Nejman-Gryz P., Grubek-Jaworska $H$. The use of selected commercial molecular assays for microbiological diagnosis of tuberculosis. Pneumonol. Alergol. Pol. 2012; 80: 6-12.

14. Tortoli E. Diagnosi immunologia della tuberculosi. http://www. mycobactoscana.it/Testi/Interferon.pps; 02.07.2014.

15. Ahmad S. Pathogenesis, immunology, and diagnosis of latent Mycobacterium tuberculosis infection. Clin. Dev. Immunol. 2011; 2011: 814943.

16. Gupta D., Agarwal R., Aggarwal A.N., Jindal S.K. Molecular evidence for the role of mycobacteria in sarcoidosis: a meta-analysis. Eur. Respir. J. 2007; 30: 508-516.

17. Lillebaek T., Dirksen A., Baess I. et al. Molecular evidence of endogenous reactivation of Mycobacterium tuberculosis after 33 years of latent infection. J. Infect. Dis. 2002; 185: 401-404.

18. McAdams H.P., Erasmus J., Winter J.A. Radiologic manifestations of pulmonary tuberculosis. Radiol. Clin. North Am. 1995; 33: 655-678.

19. Horsburgh C.R. Jr,. Rubin E.J. Clinical practice. Latent tuberculosis infection in the United States. N. Engl. J Med. 2011; 364: 1441-1448.

20. Boehme C.C., Nabeta P., Hillemann D. et al. Rapid molecular detection of tuberculosis and rifampin resistance. N. Engl. J. Med. 2011; 363: 1005-1015.

21. Denkinger C., Schumacher S.G., Boehme C.C. et al. Xpert MTB/ RIF assay for the diagnosis of extrapulmonary tuberculosis: a systematic review and meta-analysis. Eur. Respir. J. 2014 Apr 2 [Epub ahead of print as doi: 10.1183/09031936.00007814].

22. Tortoli E., Russo C., Piersimoni C. et al. Clinical validation of Xpert MTB/RIF for the diagnosis of extrapulmonary tuberculosis. Eur. Respir. J. 2012; 40: 442-447.

23. Ishige I., Usui Y., Takemura T., Eishi Y. Quantitative PCR of mycobacterial and propionibacterial DNA in lymph nodes of Japanese patients with sarcoidosis. Lancet 1999; 354: 120-123.

24. Zhou Y., Li H.P., Li Q.H. et al. Differentiation of sarcoidosis from tuberculosis using real-time PCR assay for the detection and quantification of Mycobacterium tuberculosis. Sarcoidosis Vasc. Diffuse Lung. Dis. 2008; 25: 93-99.

25. Chawla K., Gupta S., Mukhopadhyay Ch., Rao P.S., Bhat S.S. PCR for M. tuberculosis in tissues samples. J. Infect. Dev. Countr. 2009; 3: 83-87.

26. Zalecenia Polskiego Towarzystwa Chorób Płuc dotyczące rozpoznawania, leczenia i zapobiegania gruźlicy u dorosłych i dzieci. Pneumonol. Alergol. Pol. 2013; 81: 323-379. 
